\title{
Research on the Interaction Measurement Method of Urbanization and Greenization
}

\author{
Liangwen Yue ${ }^{1,2}$ \\ ${ }^{1}$ China Center for Industrial Security Research, Beijing Jiaotong University; No.3, Shangyuancun, \\ Haidian District, Beijing, 100044, P. R. China; \\ ${ }^{2}$ Beijing Center for Industrial Security and Development Research. \\ liangwenylw@163.com.
}

\begin{abstract}
This paper directed the limitation of the research on the interaction between urbanization and greenization, contructed an interaction measurement method of urbanization and greenization based on the coupling theory in physics; and gave an empirical test and analysis on the support of Chinese provincial regional data for the year 2014. Study results confirms: the urbanization and greenization comprehensive development indicator of this paper contructed can accurately reflect the comprehensive development of China's urbanization and greenization; and the interaction measurement method of urbanization and greenization of this paper contructed is a scientific and comprehensive measurement method of coincidencing the idea of sustainable development. The method has considerable significance theoretical innovation and practical application, can measure and analyz availably the interaction between urbanization and greenization, provide decision references and theory supports for a nation or a region to develop the green economy, build green city, realize sustainable development.
\end{abstract}

Keywords: urbanization; greenization; coupling coordination degree; sustainable development; green city.

\section{Introduction}

Urbanization is a necessary stage for all countries around the world to realize the process of modernization. With the rapid development of industrialization, the urbanization process has been rapidly developed since the industrial revolution. In the process of urbanization, a series of ecological environmental problems have been produced, and how to promote the interaction development of urbanization and greenization is the problem that every country needs to face.But the research about the greenization has just begun, and the research about the interaction and coordination development of urbanization and greenization is very little, it is difficult to guide the formation of practice. Therefore, it has a significant theoretical and practical significance to research theory and practice of the interaction of urbanization and greenization, for human society to create green city, and to realize sustainable development finally. Based on the above considerations, this paper contructed an interaction measuring method of urbanization and greenization based on the coupling theory in physics; and gave an empirical test and analysis on the support of Chinese provincial regional data for the year 2014.

\section{The related research review}

\subsection{The literatures review of related problems}

The related literatures review of urbanization and greenization are as follows.Lin and Liu studied influence factors of carbon emission during the urbanization of China, and gave the suggestion of reducing carbon emissions [1]. At present, the concept of green growth with the highest citation rate is given by OECD [2]. Campiglio [3] explored green growth in the service industry. Mathews and Reinert [4] researched the role of renewable energy, clean technology and resource recycling systems on the green economy. Jakob and Edenhofer [5] considered green growth is the economic growth model of enhancing"social welfare" and "human happiness".Dercon [6] studied the role of green 
growth on climate change and aiding poor countries. McKendry and Janos [7] discussed green growth and sustainable development of industrial cities in developed countries. Feng etc. [8] explored the concept of greenization. Ding etc. [9] give a general introduction on progress of coordinated development of industrialization, urbanization, agricultural modernization, informationization, and greenization in China, and other literatures, etc.

\subsection{Limitations of existing research}

(1)The research on the urbanization needs to be further deepened at home and abroad.

(2)The research on the greenization is at the initial stage, and the research is not deep enough, and the research has not formed theoretical system.

(3)The interaction research of urbanization and greenization is less, and it is difficult to guide the practice.

\section{Interaction measuring method of urbanization and greenization}

This paper directed the limitation of the research on the interaction between urbanization and greenization, contructed an interaction measurement method of urbanization and greenization based on the coupling theory in physics.

\subsection{Interaction measurement indicators system of urbanization and greenization}

This paper contructed an interaction measurement indicator of urbanization and greenization, Table 1 is the measurement indicators system. In this paper, we use the factor analysis method to synthesize 5 indicators (proportion of urban population etc.) into urbanization comprehensive index. Similarly, we use the factor analysis method to synthesize 5 indicators (renewable energy power generation ratio etc.) into greenization comprehensive index.

Table 1 Interaction measurement indicators system of urbanization and greenization

\begin{tabular}{|c|c|c|c|}
\hline & $\begin{array}{l}\text { Urbanization } \\
\text { and } \\
\text { greenization }\end{array}$ & Evaluation indicator & Concrete representation \\
\hline \multirow{10}{*}{$\begin{array}{l}\text { Interaction } \\
\text { degree of } \\
\text { urbanization } \\
\text { and } \\
\text { greenization }\end{array}$} & \multirow{5}{*}{$\begin{array}{l}\text { Urbanization } \\
\text { comprehensive } \\
\quad \text { index }\end{array}$} & Proportion of urban population & Urban population /total population (ratio) \\
\hline & & $\begin{array}{c}\text { Urban employment population } \\
\text { accounts for the proportion of total } \\
\text { employed population }\end{array}$ & $\begin{array}{l}\text { The number of urban employed population/total } \\
\text { employed population (ratio) }\end{array}$ \\
\hline & & $\begin{array}{c}\text { proportion of non-agricultural } \\
\text { industry } \\
\end{array}$ & $\begin{array}{c}\text { Second and third industry added } \\
\text { value/GDP(ratio) } \\
\end{array}$ \\
\hline & & $\begin{array}{c}\text { Engel coefficient of urban } \\
\text { residents }\end{array}$ & $\begin{array}{l}\text { Residents food expenditure gross/total personal } \\
\text { consumption expenditure (ratio) }\end{array}$ \\
\hline & & $\begin{array}{l}\text { Per capita disposable income of } \\
\text { urban residents }\end{array}$ & (yuan/person) \\
\hline & \multirow{5}{*}{$\begin{array}{l}\text { Greenization } \\
\text { comprehensive } \\
\quad \text { index }\end{array}$} & $\begin{array}{l}\text { Renewable energy power } \\
\text { generation ratio }\end{array}$ & $\begin{array}{l}\text { Renewable energy power generation accounts } \\
\text { for the proportion of total energy power } \\
\text { generation (percentage) }\end{array}$ \\
\hline & & Per capita sulfur dioxide emissions & $\begin{array}{l}\text { Annual average sulfur dioxide emissions per } \\
\text { capita(ton/person) }\end{array}$ \\
\hline & & $\begin{array}{c}\text { Investment proportion of } \\
\text { environmental pollution } \\
\text { government }\end{array}$ & $\begin{array}{l}\text { Environmental pollution government investment } \\
\text { accounted for GDP (percentage) }\end{array}$ \\
\hline & & GDP energy intensity & $\begin{array}{l}\text { Ten thousand yuan GDP energy } \\
\text { consumption(tons of standard coal) }\end{array}$ \\
\hline & & Forest coverage & $\begin{array}{l}\text { Regional annual average forest coverage } \\
\text { (percentage) }\end{array}$ \\
\hline
\end{tabular}

\subsection{Coupling degree model and coupling coordination degree model}

In this paper, the coupling theory of physics subject is introduced, which is used to explore the interaction degree measurement of urbanization and greenization. The model of coupling theory used in this paper is as follows.

\subsubsection{Coupling degree model}

Coupling degree model of physics subject is as follows: 


$$
C_{n}=\left\{\frac{\left(U_{1} \times U_{2} \times \ldots \times U_{n}\right)}{\Pi\left(U_{i}+U_{j}\right)}\right\}^{1 / n}
$$

In the above formula, $U_{1}, U_{2}, \cdots, U_{n}$ represent n systems, $C_{n}$ represent Coupling degrees of the $\mathrm{n}$ systems.

There are two systems (urbanization and greenization) in this paper, so, the coupling degree of the two systems is as follows:

$$
C=C_{2}=\left\{\frac{\left(U_{1} \times U_{2}\right)}{\left(U_{1}+U_{2}\right)^{2}}\right\}^{1 / 2}
$$

In the above formula, $U_{1}$ represent urbanization comprehensive index, and $U_{2}$ represent greenization comprehensive index, and $C_{2}$ represent coupling degree index $\mathrm{C}$ of the two systems, $0 \leq C<1$.

\subsubsection{Coupling coordination degree model}

Coupling degree index $\mathrm{C}$ express two system coupling degree, but it can't reflect the actual interaction and coordination degree of the two systems. Therefore, we need to introduce coupling coordination index $\mathrm{D}$ to measure the degree of interaction between the two systems.

$$
\begin{aligned}
& D=\sqrt{C \times T} \\
& T=\alpha u_{1}+\beta u_{2}
\end{aligned}
$$

Among them, D represent coupling coordination index, expresses the degree of interaction of the systems. T represent comprehensive evaluation index of two systems, reflect the overall efficiency of the two systems. $\alpha$ and $\beta$ represent undetermined coefficients. Generally speaking, we think that urbanization and greenization are equally important. So, $\alpha$ and $\beta$ values are the same, both are 0.5 .

\subsection{Interactive degree measurement standard of urbanization and greenization}

\begin{tabular}{|c|c|c|c|c|c|}
\hline $\begin{array}{c}\text { Interactive } \\
\text { development } \\
\text { phase }\end{array}$ & $\begin{array}{c}\text { Coupling } \\
\text { coordination } \\
\text { degree of D value }\end{array}$ & Interaction type & $\begin{array}{c}\text { Interactive } \\
\text { development phase }\end{array}$ & $\begin{array}{c}\text { Coupling } \\
\text { coordination } \\
\text { degree of D value }\end{array}$ & $\begin{array}{l}\text { Interaction } \\
\text { type }\end{array}$ \\
\hline \multirow{3}{*}{$\begin{array}{c}\text { Low level } \\
\text { interaction: } \\
\text { very little } \\
\text { contact }\end{array}$} & 0.0000-0.0999 & $\begin{array}{c}\text { Extreme lack of } \\
\text { interaction }\end{array}$ & \multirow{3}{*}{$\begin{array}{l}\text { Strengthen } \\
\text { interaction: } \\
\text { running in contact }\end{array}$} & $0.5000-0.5999$ & $\begin{array}{l}\text { Reluctant } \\
\text { interaction }\end{array}$ \\
\hline & 0.1000-0.1999 & $\begin{array}{c}\text { Serious lack of } \\
\text { interaction }\end{array}$ & & 0.6000-0.6999 & $\begin{array}{c}\text { Primary } \\
\text { interaction }\end{array}$ \\
\hline & $0.2000-0.2999$ & $\begin{array}{l}\text { Moderate lack of } \\
\text { interaction }\end{array}$ & & 0.7000-0.7999 & $\begin{array}{l}\text { Intermediate } \\
\text { interaction }\end{array}$ \\
\hline \multirow{2}{*}{$\begin{array}{c}\text { Start } \\
\text { interaction: } \\
\text { contend with } \\
\text { each other }\end{array}$} & $0.3000-0.3999$ & $\begin{array}{c}\text { Slight lack of } \\
\text { interaction }\end{array}$ & \multirow{2}{*}{$\begin{array}{l}\text { High level } \\
\text { interaction: } \\
\text { fusion and } \\
\text { symbiosis }\end{array}$} & 0.8000-0.8999 & $\begin{array}{c}\text { Good } \\
\text { interaction }\end{array}$ \\
\hline & $0.4000-0.4999$ & $\begin{array}{l}\text { On the verge of } \\
\text { lack of interaction }\end{array}$ & & $0.9000-1.0000$ & $\begin{array}{c}\text { High quality } \\
\text { interaction }\end{array}$ \\
\hline
\end{tabular}

Coupling coordination index $\mathrm{D}$ is the indicator which measures the degree of interaction and coordination between urbanization and greenization, the measuring standard is in Table 2 .

Table 2 Interactive degree measurement standard of urbanization and greenization

\section{Measurement and analysis of the interactive degree of China's urbanization and greenization}

Specific data of each indicator which is showed in table 1, of interactive measurement between China's urbanization and greenization in 2014, is derived from China Statistical Yearbook (2015), Statistical Yearbook of Chinese various provincial regions in the year 2015, China economic information network statistics database, CNKI "Statistical database of China's economic and social development", People's Republic of China "national statistical database" and other relevant statistical data. According to the interaction measurement method of urbanization and greenization presented above, we got interactive degree measurement results of China's urbanization and greenization in 2014, the results are shown in table 3. 
Table 3 Interactive degree measurement results of urbanization and greenization of Chinese provincial regions in 2014

\begin{tabular}{|c|c|c|c|c|c|}
\hline $\begin{array}{l}\text { Geographical } \\
\text { district }\end{array}$ & $\begin{array}{l}\text { Provincial } \\
\text { region }\end{array}$ & $\begin{array}{l}\text { Coupling } \\
\text { degree } \\
\text { index C }\end{array}$ & $\begin{array}{l}\text { Comprehensive } \\
\text { evaluation } \\
\text { index } \mathrm{T}\end{array}$ & $\begin{array}{l}\text { Coupling } \\
\text { coordination } \\
\text { index D }\end{array}$ & Interactive degree measurement \\
\hline North China & $\begin{array}{l}\text { Beijing } \\
\text { Tianjin } \\
\text { Hebei } \\
\text { Shanxi } \\
\text { Inner } \\
\text { Mongolia }\end{array}$ & $\begin{array}{l}0.4975 \\
0.4961 \\
0.4513 \\
0.4452 \\
0.4480\end{array}$ & $\begin{array}{l}0.8924 \\
0.8761 \\
0.7483 \\
0.6142 \\
0.6259\end{array}$ & $\begin{array}{l}0.6663 \\
0.6593 \\
0.5811 \\
0.5229 \\
0.5295\end{array}$ & $\begin{array}{l}\text { Primary interaction } \\
\text { Primary interaction } \\
\text { Reluctant interaction } \\
\text { Reluctant interaction } \\
\text { Reluctant interaction }\end{array}$ \\
\hline $\begin{array}{l}\text { Northeast } \\
\text { China }\end{array}$ & $\begin{array}{l}\text { Heilongjiang } \\
\text { Jilin } \\
\text { Liaoning }\end{array}$ & $\begin{array}{l}0.4741 \\
0.4763 \\
0.4862\end{array}$ & $\begin{array}{l}0.7328 \\
0.7695 \\
0.8147\end{array}$ & $\begin{array}{l}0.5894 \\
0.6054 \\
0.6294\end{array}$ & $\begin{array}{l}\text { Reluctant interaction } \\
\text { Primary interaction } \\
\text { Primary interaction }\end{array}$ \\
\hline East China & $\begin{array}{l}\text { Shanghai } \\
\text { Jiangsu } \\
\text { Zhejiang } \\
\text { Anhui } \\
\text { Fujian } \\
\text { Shandong } \\
\text { Jiangxi } \\
\end{array}$ & $\begin{array}{l}0.4993 \\
0.4918 \\
0.4926 \\
0.4825 \\
0.4894 \\
0.4870 \\
0.4857 \\
\end{array}$ & $\begin{array}{l}0.8973 \\
0.8560 \\
0.8592 \\
0.6534 \\
0.8429 \\
0.8365 \\
0.6791 \\
\end{array}$ & $\begin{array}{l}0.6693 \\
0.6488 \\
0.6506 \\
0.5615 \\
0.6423 \\
0.6383 \\
0.5743 \\
\end{array}$ & $\begin{array}{l}\text { Primary interaction } \\
\text { Primary interaction } \\
\text { Primary interaction } \\
\text { Reluctant interaction } \\
\text { Primary interaction } \\
\text { Primary interaction } \\
\text { Reluctant interaction } \\
\end{array}$ \\
\hline $\begin{array}{l}\text { Central } \\
\text { China }\end{array}$ & $\begin{array}{c}\text { Henan } \\
\text { Hubei } \\
\text { Hunan }\end{array}$ & $\begin{array}{l}0.4782 \\
0.4671 \\
0.4758\end{array}$ & $\begin{array}{l}0.6974 \\
0.7582 \\
0.7146\end{array}$ & $\begin{array}{l}0.5775 \\
0.5951 \\
0.5831\end{array}$ & $\begin{array}{l}\text { Reluctant interaction } \\
\text { Reluctant interaction } \\
\text { Reluctant interaction }\end{array}$ \\
\hline South China & $\begin{array}{l}\text { Guangdong } \\
\text { Guangxi } \\
\text { Hainan }\end{array}$ & $\begin{array}{l}0.4932 \\
0.4815 \\
0.4839 \\
\end{array}$ & $\begin{array}{l}0.8631 \\
0.6328 \\
0.7224 \\
\end{array}$ & $\begin{array}{l}0.6524 \\
0.5520 \\
0.5912 \\
\end{array}$ & $\begin{array}{l}\text { Primary interaction } \\
\text { Reluctant interaction } \\
\text { Reluctant interaction }\end{array}$ \\
\hline $\begin{array}{l}\text { Southwest } \\
\text { China }\end{array}$ & $\begin{array}{l}\text { Chongqing } \\
\text { Sichuan } \\
\text { Guizhou } \\
\text { Yunnan } \\
\text { Tibet }\end{array}$ & $\begin{array}{l}0.4791 \\
0.4653 \\
0.4475 \\
0.4592 \\
0.3991\end{array}$ & $\begin{array}{l}0.7819 \\
0.6835 \\
0.5626 \\
0.5942 \\
0.5294\end{array}$ & $\begin{array}{l}0.6121 \\
0.5639 \\
0.5018 \\
0.5224 \\
0.4597\end{array}$ & $\begin{array}{c}\text { Primary interaction } \\
\text { Reluctant interaction } \\
\text { Reluctant interaction } \\
\text { Reluctant interaction } \\
\text { On the verge of lack of } \\
\text { interaction } \\
\end{array}$ \\
\hline $\begin{array}{c}\text { Northwest } \\
\text { China }\end{array}$ & $\begin{array}{l}\text { Shaanxi } \\
\text { Gansu } \\
\text { Qinghai } \\
\text { Ningxia } \\
\text { Xinjiang }\end{array}$ & $\begin{array}{l}0.4778 \\
0.4294 \\
0.4317 \\
0.3972 \\
0.4381\end{array}$ & $\begin{array}{l}0.7610 \\
0.4835 \\
0.5491 \\
0.4927 \\
0.5748\end{array}$ & $\begin{array}{l}0.6030 \\
0.4556 \\
0.4869 \\
0.4424 \\
0.5018\end{array}$ & $\begin{array}{c}\text { Primary interaction } \\
\text { On the verge of lack of } \\
\text { interaction } \\
\text { On the verge of lack of } \\
\text { interaction } \\
\text { On the verge of lack of } \\
\text { interaction } \\
\text { Reluctant interaction }\end{array}$ \\
\hline
\end{tabular}

The data in table 3 are analysed as follows.In the interactive degree of China's provincial regional urbanization and greenization in 2014, Shanghai, Beijing, Tianjin, Guangdong, Zhejiang, Jiangsu, Fujian, Shandong, Liaoning, Chongqing, Jilin, Shaanxi belong to the primary interaction. Hubei , Hainan, Heilongjiang, Hebei, Hunan, Henan, Jiangxi, Sichuan, Anhui, Guangxi, Inner Mongolia, Shanxi, Yunnan, Guizhou, Xinjiang belong to reluctant interaction. Qinghai, Tibet, Gansu, Ningxia belong to on the verge of lack of interaction. Overall, there are interactions in China's provincial regional urbanization and greenization in 2014, but the degree and level of interaction is not high.The interactive degree of urbanization and greenization is determined by the comprehensive factors, and generally speaking, the developed region of economy, science and technology, social development, urbanization degree, green economy, the interaction between urbanization and greenization is relatively high. At present, the urbanization and greenization strategy whichi is implemented in China's national level, is an opportunity for the China's provincial region. Every province should hold this opportunity, vigorously promote the local area of urbanization and greenization, and promote the interaction between urbanization and greenization; This is a necessary way which is used to narrow 
the regional gap, to make China as a whole realize modernization, and to achieve sustainable development.

\section{Conclusion}

This paper directed the limitation of the research on the interaction between urbanization and greenization, contructed an interaction measurement method of urbanization and greenization based on the coupling theory in physics; and gave an empirical test and analysis on the support of Chinese provincial regional data for the year 2014. Study results confirms: the urbanization and greenization comprehensive development indicator of this paper contructed can accurately reflect the comprehensive development of China's urbanization and greenization; and the interaction measurement method of urbanization and greenization of this paper contructed is a scientific and comprehensive measurement method of coincidencing the idea of sustainable development. The method has considerable significance theoretical innovation and practical application, can measure and analyz availably the interaction between urbanization and greenization, provide decision references and theory supports for a nation or a region to develop the green economy, build green city, realize sustainable development.

\section{Acknowledgements}

This study is supported by The National Natural Science Foundation Major International (Regional) Joint Program of China (No.71320107006); The National Social Science Foundation Key Projects of China (No.14AZD090).

\section{References}

[1] Lin Boqiang, Liu Xiying. China's Carbon Dioxide Emissions under the Urbanization Process: Influence Factors and Abatement Policies [J]. Economic Research Journal, 2010, (8):66-78.

[2] OECD. Towards Green Growth [R]. OECD Publishing, 2011:1-144.

[3] Campiglio Emanuele. The structural shift to green services: a two-sector growth model with public capital and open-access resources [J].Structural Change and Economic Dynamics, 2014, 30:148-161.

[4] Mathews John A, Reinert Erik S. Renewables, manufacturing and green growth Energy strategies based on capturing increasing returns [J]. Futures, 2014, 61:13-22.

[5] Jakob Michael, Edenhofer Ottmar. Green growth, degrowth, and the commons [J]. Oxford Review of Economic Policy, 2014, 30(3):447-468.

[6] Dercon Stefan. Climate change, green growth, and aid allocation to poor countries [J]. Oxford Review of Economic Policy, 2014, 30(3):531-549.

[7] McKendry Corina, Janos Nik. Greening the industrial city: equity, environment, and economic growth in Seattle and Chicago [J]. Int Environ Agreements, 2015, 15:45-60.

[8] Feng Zhijun, Liu Yanhua, Jin Yong, Guo Qiang, Yan feng. To persist and improve the greenization road of Chinese characteristics [J]. China Soft Science, 2015, (9):1-7.

[9] Ding Zhiwei, Zhang Gaisu, Wang Fazeng, Kang Jiayu, Gao Ling. Progress on quantitative evaluation of coordinated development ofindustrialization, urbanization, agricultural modernization, informationization, and greenization in China and reflections [J]. Progress in Geography, 2016, 35(1):4-13. 